Jurnal KONTEKSTUAL

Volume 01, No. 1, Agustus 2019, p. 63-69

\title{
HUBUNGAN ANTARA DISIPLIN DAN MOTIVASI DENGAN PRESTASI BELAJAR SISWA KELAS III
}

\author{
Siti Fatimah ${ }^{1}$, Rizki Umi Nurbaet ${ }^{2}$, Budi Adjar Pranoto*3 \\ 1,2,3Prodi Pendidikan Guru Sekolah Dasar Fakultas Keguruan dan Ilmu Pendidikan \\ Universitas Muhadi Setiabudi Brebes, Indonesia \\ Corresponding Author: *budiadjar@gmail.com
}

\begin{abstract}
Abstrak
Masalah dalam penelitian ini adalah rendahnya disiplin belajar dan motivasi belajar kelas III SD Negeri Bandungsari 01. Tujuan dalam penelitian ini adalah untuk mengetahui hubungan antara disiplin belajar dan motivasi belajar dengan prestasi belajar pada siswa kelas III SD Negeri Bandungsari 01. Metode penelitian yang digunakan dalam penelitian ini adalah kuantitatif korelasional. Teknik pengumpulan data menggunakan angket, lembar observasi dan dokumentasi. Analisis statistic yang digunakan yaitu uji normalitas, uji linieritas, dan uji hipotesis. Uji Chi kuadrat untuk menguji normalitas data. Uji anova untuk menghitung linieritas data. Uji product moment untuk hipotesis. Semua perhitungan tersebut diolah dengan menggunakan program SPSS versi 21. Berdasarkan uji product moment nilai sig. (2-taled) antara disiplin belajar $(X 1)$ dengan prestasi $(Y)$ adalah sebesar 0,000 $<0,05$ yang berarti terdapat korelasi yang signifikan antara variable disiplin belajar dengan variable prestasi belajar. Selanjutnya hubungan antara motivasi belajar (X2) dengan prestasi belajar (Y) memiliki nilai sig. (2-taled) sebesar 0,000 < 0,05, yang berarti terdapat korelasi yang signifikan antara variabel motivasi belajar dengan variabel prestasi belajar. Jadi simpulan penelitian ini adalah terdapat hubungan antara disiplin belajar dan motivasi belajar terhadap prestasi belajar.
\end{abstract}

Kata kunci :Disiplin Belajar, Motivasi Belajar, Prestasi Belajar

\begin{abstract}
The problem in this research is the low discipline of learning and motivation to learn grade III of SD Negeri Bandungsari 01 District Banjarharjo District Brebes. The aim in this study was to know the relationship between learning discipline and learning motivation with the achievement of learning in grade III students of the Bandungsari State Elementary School 01. The research methods used in this research are quantitative correlational. The population in this study is all students of the class III Bandungsari State Elementary School 01 number 21 students. The sample in this study is the total population. Data collection techniques using polls, observation sheets and documentation. The statistic analysis used is test normality, linierity test, and hypothesis test. Test the Chi squared to test the normality of data. ANOVA test to calculate data interference linearity. Test the product moment for hypotheses. All calculations are processed using SPSS program version 21. Based on the test product moment the value of sig. (2-taled) between learning discipline $(X 1)$ with achievement $(Y)$ is $0.000<0.05$, which means there is a significant correlation between variable discipline learning with variable learning achievement. Furthermore the relationship between learning motivation (X2) with learning achievement $(Y)$ has a value of sig. (2-taled) of $0.000<0.05$, which means there is a significant correlation between learning motivation variables with learning achievement variables. So the conclusion of this research is there is a link between learning discipline and motivation to learn to study achievement.
\end{abstract}

Keywords: learning discipline, learning motivation, learning achievement

Submitted: 13 Agustus 2019, Accepted: 18 Agustus 2019, Published: Agustus 2019 ISSN: xxxx-Xxxxx (online), Website: http://jurnal.umus.ac.id/index.php/kontekstual 


\section{PENDAHULUAN}

Pendidikan merupakan suatu hal yang sangat penting dan tidak dapat dipisahkan dari kehidupan seseorang dalam masyarakat dan bangsa.Kemajuan suatu bangsa juga ditentukan oleh tingkat keberhasilan pendidikan. Tujuan pendidikan nasional menurut undang-undang No. 20 Tahun 2003 tentang Sistem Pendidikan Nasional masyarakat bahwa:

Pendidikan nasional berfungsi mengembangkan kemampuan dan membentuk watak serta peradaban bangsa, bertujuan untuk berkembangnya potensi siswa agar menjadi manusia yang beriman dan bertakwa kepada Tuhan Yang Maha Esa, berahlak mulia, sehat, berilmu, cakap, kreatif, mandiri dan menjadi warga negara yang demokratis serta bertanggung jawab.

Dan fungsi pendidikan tersebut jelas kita sadari bahwa pendidikan akan mempersiapkan seorang siswa untuk hidup dengan baik di dalam kehidupannya.

Tujuan pendidikan adalah untuk menumbuhkan wawasan dan kesadaran bernegara, sikap serta perilaku yang cinta tanah air dan bersendikan kebudayaan bangsa, wawasan nusantara, serta ketahanan nasional dalam diri para calon-calon penerus bangsa yang sedang dan mengkaji dan akan menguasai ilmu pengetahuaan dan teknologi serta seni. Selain itu juga bertujuan untuk meningkatkan kualitas manusia Indonesia yang berbudi luhur, berkepribadian, mandiri, maju, tangguh, profesional, bertanggung jawab, dan produktif serta sehat jasmani dan rohani. Melalui pendidikan kewarganegaraan warga negara Kesatuan Republik Indonesia. diharapkan mampu memahami, menganalisa dan menjawab masalahmasalah yang dihadapi masyarakat, bangsa dan negara [1].
Prestasi belajar yang baik tentu diinginkan oleh siswa, pada kenyataanya tidak semua siswa mendapat prestasi belajar yang memuaskan sesuai dengan apa yang diharapkan. Rendahnya prestasi belajar siswa kelas III pada muatan Pendidikan Kewarganegaraan ini diketahui dari nilai rata-rata siswa hanya 63 pada saat Penilaian Tengah Semester II (PTS) tahun pelajaran 2018/2019 menunjukan masih banyak siswa menapatkan nilai di bawah Kriteria Ketuntasan Minimal (KKM) yang telah di tetapkan yaitu 64 .

Selain itu dalam pelaksanaan pembelajaran di sekolah, masih ada siswa yang kurang disiplin dalam belajar, peraturan dan tata tertib yang ada di sekolah kurang di tegakkan dan kurang terlaksana oleh peserta didik, seorang siswa dapat dikatakan disiplin belajar tinggi apabila siswa itu tunduk pada peraturan dan tata tertib yang berlaku disekolah.

Berbicara tentang disiplin, sangat berkaitan erat dengan motivasi. Menurut peneliti [2] salah satu yang mempengaruhi perkembangan disiplin adalah motivasi, karena jika seseorang memahami apa yang diinginkan dan apa yang harus dilakukan untuk hidup terasa lebih nyaman, menyenangkan, sehat dan sukses, akan memotivasi siswa untuk membuat perencanaan hidup dan mematuhi perencanaan yang dibuat atas kemauan dan kesadaran dirinya sendiri, sehingga akan menumbuhkan sikap disiplin dalam diri seseorang.

Berdasarkan uraian tersebut penulis tertarik untuk melakukan penelitian tentang "Hubungan antara Disiplin Belajar dan Motivasi Belajar dengan Prestasi Belajar Pendidikan Kewarganegaraan pada Siswa Kelas 3 SD Negeri Bandungsari 01".

Tujuan di adakannya penelitian ini adalah: 1) untuk mengetahui adanya hubungan antara disiplin belajar dengan 
prestasi belajar PKn pada kelas III SD $\mathrm{N}$ Bandungsari 01; 2) untuk mengetahui adanya hubungan antara motivasi belajar dengan prestasi belajar PKn pada kelas III SD N Bandungsari 01 ; 2) untuk mengetahui adanya hubungan antara disiplin belajar dan motivasi belajar dengan prestasi belajar PKn pada siswa selas III di SD Negeri Bandungsari 01.

\section{KAJIAN TEORI}

Seorang siswa yang memliki disiplin belajar yang baik akan mempunyai kecakapan mengenai cara belajar. Hasl ini sangat diperlukan guna tercapainya hasil, sebab berhasil tidaknya siswa dalam usahanya pada dasarnya tergantung pada bagaimana ia melakukan cara-cara belajar yang baik. Seperti yang dikemukakan oleh peneliti [3] yaitu agar siswa lebih maju, siswa harus disiplin didalam belajar baik disekolah, dirumah maupun di perpustakaan.

Aktivitas belajar sehari-hari tidak lepas dari motivasi, artinya setiap aktivitas belajar yang kita lakukan pasti didukung rasa keinginan yang muncul dari dalam diri kita. Hal ini karena motivasi juga ikut berperan menentukan kesuksesan suatu kegiatan yang kita lakukan. Adanya keinginan yang mengaktifkan, menggerakkan, menyalurkan, dan mengarahkan sikap dan perilaku individu untuk belajar dalam memotivasi siswa[4].

$$
\text { Prestasi belajar adalah }
$$

perubahan tingkah laku yang diharapkan pada siswa setelah dilakukan proses mengajar[5]. Sedangkan menurut peneliti [6] bahwa prestasi belajar adalah hasil yang dicapai dan perwujudan prestasi dapat dilihat dengan nilai yang diperoleh dari setelah mengikuti tes.

Maka penulis dapat menyimpulkan bahwa prestasi belajar adalah penguasaan ilmu pengetahuan atau keterampilan yang lazim ditunjukan dalam angka atau huruf yang diberikan seorang guru kepada seseorang setelah ia menjalankan usaha belajar.

\section{METODE PENELITIAN}

Penelitian ini merupakan penelitian kuantitatif dengan desain penelitian korelasional. Penelitian dilaksanakan di kelas III SD Negeri Bandungsari 01 yang terletak di Jl.Nyagak Desa Bandungsari Kecamatan Banjarharjo Kabupaten Brebes. Pelaksanaan dilakukan pada bulan Januari 2019.

Populasi pada penelitian ini adalah semua siswa kelas III yang berada di SD Negeri Bandungsari 01 tahun ajaran 2018/2019 yang berjumlah 21 siswa dengan jumlah siswa laki-laki sebanyak 13 siswa dan siswa perempuan sebanyak 8 siswa.Sampel pada penelitian ini sebanyak 21 siswa kelas III SD Negeri Bandungsari 01 tahun ajaran 2018/2019.

Teknik sampel yang akan digunakan dalam penelitian ini adalah Sampling Jenuh (Sensus) menurut (Sugiyono, 2015: 124-125) SamplingJenuh (Sensus) adalah teknik penentuan sampel bila semua anggota populasi digunakan sebagai sampel. Hal ini sering dilakukan bila jumlah populasi relatif kecil, kurang dari 30 orang, atau penelitian yang ingin membuat generalisasi dengan kesalahan yang sangat kecil. Jadi, jumlah responden sebanyak 20 siswa kelas III SD Negeri Bandungsari 01 (keseluruhan dari populasi penelitian).

Teknik pengumpulan data dalam penelitian ini adalah 1) Kuesioner atau angket adalah alat pengumpulan data yang dilakukan dengan cara memberi seperangkat pertanyaan atau pernyataan tertulis kepada reponden untuk menjawabnya[7]. Angket ini digunakan 
untuk memperoleh data tentang motivasi belajar siswa. Pada penelitian ini, akan menggunakan angket tertutup dalam pengumpulan data. Angket tertutup adalah angket yang menghendaki jawaban pendek, atau jawabannya diberikan dengan membubuhkan tanda tertentu. Angket disusun dengan disertai alterrnatif jawaban. 2) Lembar observasi Menurut peneliti [7] Observasi merupakan cara yang penting untuk mendapatkan informasi yang pasti tentang orang, karena apa yang dikatakan orang belum tentu sama dengan apa yang dikerjakan. Dalam penelitian ini Lembar Observasi di gunakan untuk mengambil data disiplin belajar. 3) Menurut peneliti [8] metode dokumentasi, yaitu mencari data mengenai hal-hal atau variable yang berupa catatan, transkip, buku dan sebagainya.Dalam penelitian ini dokumentasi diguakan untuk mengetahui prestasi belajar siswa.

Teknik analisis data merupakan cara yang digunakan untuk menguraikan keterangan-keterangan atau data yang diperoleh agar data tersebut dapat dipahami bukan oleh orang yang mengumpulkan data saja, tapi juga oleh orang lain. Tahap pengolahan data yang dilakukan dalam penelitian ini meliputi.

1. Pengujian Prasyarat

Analisis Persyaratan analisis data meliputi normalitas dan linieritas. Uji normalitas dan uji linieritas dilakukan terlebih dahulu sebelum dilakukan uji hipotesis. Uji normalitas dilakukan untuk mengetahui apakah data penelitian berdistribusi normal atau tidak. Uji normalitas ini menggunakan Chi Kuadrat. Uji Linieritas setelah dilakukan uji normalias maka di lakukan denga uji linieritas untuk mengetahui apakah ada hubungan linier atau tidak antara variable bebas terhadap variable terikat. Hubungan pervariabel yaitu motivasi belajar dan prestasi belajar terhadap prestasi beelajar siswa. Pengujian linieritas pada SPSS dengan menggunakan Test for Linearity pada taraf signifikansi 0,05. Dua variabel dikatakan mempunyai hubungan yang linear bila nilai signifikansi < 0,05 .

2. Uji Hipotesis

Untuk menguji hipotesis yang telah dirumuskan maka langkah yang harus ditempuh yakni sebagai berikut: Uji parsial $t\left(\mathrm{X}_{1}\right.$ terhadap $\mathrm{Y}$ ) dan $\left(\mathrm{X}_{2}\right.$ terhadap $\left.\mathrm{Y}\right)$. Uji korelasi Product Moment Teknik analisis product moment digunakan untuk menguji hipotesis (1) dan (2) yaitu untuk mengetahui hubungan antar variabel bebas dan antara variabel bebas dengan variabel terikat. Koefisien Determinasi, Koefisien determinasi adalah kuadrat dari koefisien korelasi yang dikalikan dengan $100 \%$. Hal ini dilakukan untuk mengetahui seberapa besar variable $\mathrm{X}$ mempunyai sumbangan atau ikut menentukan variabel Y. Untuk mengetahui seberapa pengaruh variabel $X$ terhadap variabel $\mathrm{Y}$ yaitu dapat dilihat pada tabel Model Summary kolom R Square. Kemudian angka tersebut diubah ke dalam bentuk persen.

\section{HASIL DAN PEMBAHASAN \\ Hasil}

Berdasarkan analisis data bahwa terdapat hubungan antara disiplin dan motivasi dengan prestasi belajar pendidikan kewarganegaraan pada siswa kelas III di SD Negeri Bandungsari 01. Hal ini dapat dijelaskan sebagai barikut:

1. Deskripsi data

Penelitian ini merupakan penelitian korelasi yang menggunakan tiga 
variabel yaitu variabel disiplin belajar dan motivasi belajar sebagai variabel bebas dan variabel prestasi belajar sebagai variabel terikatnya. Deskripsi data dari masing-masing variabel meliputi mean, median, modus, standar deviasi, varians, nilai minimum, nilai maksimum, rentang data dan tabel distribusi frekuensi. Data penelitian diperoleh dari siswa kelas III SD Negeri Bandungsari 01.

\section{a. Disiplin Belajar}

Berdasarkan data variable disiplin belajar diperoleh nilai rata-rata sebesar 11,76, variansi sebesar 3,990, nilai minimum 8 , nilai maksimum 15 , range 7, dan standar deviaton 1,998.

\section{b. Motivasi Belajar}

Berdasarkan data variable motivasi belajar diperoleh nilai rata-rata sebesar 68,67, variansi sebesar 123,933, nilai minimum 45, nilai maksimum 81, range 36 , dan standar deviaton 11,133

\section{c. Prestasi Belajar}

Berdasarkan tabel data variable prestasi belajar diperoleh nilai rata-rata sebesar 63,00 ,variansi sebesar 54,600, nilai minimum 50, nlai maksimum 80 , range 30 , dan standar deviaton 7,389 .

\section{Uji Hipotesis}

a. Uji Parsial t

Uji t bertujuan untuk mengetahui apaah variable bebas atau independen (X1) dan (X2) secaraparsial berhubungn terhadap varibel terikat atau variable dependen. Jika $t$ hitung $>t$ table maka ada pengruh variable bebas (x) terhadap variable terikat (y) atau hipotesis diterima.

1) Uji Parsial t Disiplin Belajar Pada penelitian ini diperoleh $\mathrm{t}$ hitung disiplin belajar sebesar 5,478 t hitung lebih besar dari t tabel 2,086 sehingga
$5,478>2,086$. Sehingga ada hubungan yang signifikan disiplin belajar dengan prestasi belajar PKn siswa kelas III SDN Bandungsari 01 dengan nilai koefisien korelasi 5,478 termasuk dalam kategori cukup. Nilai koefisien determinasi (R2) sebesar 0,612 yang menunjukkan bahwa disiplin belajar memberikan kontribusi terhadap hasil belajar siswa sebesar $0,612 \times 100 \%=$ $61,2 \%$.

2) Uji Parsial t Motivasi belajar

Pada penelitian ini diperoleh $t$ hitung motivasi belajar sebesar t hitung5,293 lebih besar dari t tabel 2,086 sehingga $5,293>2,086$. Sehingga ada hubungan yang signifikan motivasi belajar dengan presatasi belajar PKn siswa kelas III SDN Bandungsari 01 dengan nilai koefisien korelasi 5,478 termasuk dalam kategori cukup.

b. Uji Koefisien Determinasi

Nilai koefisien determinasi (R2) sebesar 0,596 yang menunjukkan bahwa motivasi belajar memberikan kontribusi terhadap hasil belajar siswa sebesar $0,596 \times 100 \%=59,6 \%$.

\section{c. Uji Korelasi Product Moment}

Berdasarkan uji korelasi product moment besarnya angka koefisien determinasi ( $R$ Square) adalah 0,659 atau sama dengn $0,659 \times 100 \%=$ $65,9 \%$, angka tersebut mengandung arti bahwa variabel disiplin belajar (X1) dan motivasi belajar (X2) secara bersamasama berhubungan terhadap variabel prestasi belajar (Y) sebesar $65,9 \%$.

\section{Pembahasan}

Hasil penelitian membuktikan bahwa disiplin belajar dan motivasi belajar mempunyai hubungan signifikan dengan hasil belajar PKn siswa kelas III SDN Bandungsari, kecamatan Banjarharjo, Kabupaten Brebes. 
Variabel bebas dalam penelitian ini adalah disiplin belajar (X1) dan Motivasi belajar (X2) dan variabel terikatnya adalah Prestasi belajar PKn. Dengan adanya hubungan positif antar tiga variabel tersebut, dapat disimpulkan jika tingkat disiplin belajar siswa mengalami perubahan, tingkat motivasi siswa mengalami perubahan, hasil belajar PKn juga akan mengalami perubahan. Semakin tinggi tingkat disiplin belajar dan motivasi belajar semakin tinggi pula prestasi belajarnya, dan semakin rendah disiplin belajar dan motivasi belajar semakin rendah juga prestasi belajarnya.

Pada penelitian ini diperoleh $t$ hitung disiplin belajar sebesar 5,478 t hitung lebih besar dari t tabel 2,086 sehingga 5,478 > 2,086. Sehingga ada hubungan yang signifikan disiplin belajar dengan prestasi belajar PKn siswa kelas III SDN Bandungsari 01 dengan nilai koefisien korelasi 5,478 termasuk dalam kategori cukup. Nilai koefisien determinasi (R2) sebesar 0,612 yang menunjukkan bahwa disiplin belajar memberikan kontribusi terhadap hasil belajar siswa sebesar $0,612 \times 100 \%=61,2 \%$.

Pada penelitian ini diperoleh $t$ hitung motivasi belajar sebesar t hitung 5,293 lebih besar dari t tabel 2,086 sehingga 5,293 > 2,086. Sehingga ada hubungan yang signifikan motivasi belajar dengan presatasi belajar PKn siswa kelas III SDN Bandungsari 01 dengan nilai koefisien korelasi 5,478 termasuk dalam kategori cukup. Nilai koefisien determinasi (R2) sebesar 0,596 yang menunjukkan bahwa motivasi belajar memberikan kontribusi terhadap hasil belajar siswa sebesar $0,596 \times 100 \%=59,6 \%$.

Berdasarkan uji korelasi product moment besarnya angka koefisien determinasi (R Square) adalah 0,659 atau sama dengn $0,659 \times 100 \%=$
$65,9 \%$, angka tersebut mengandung arti bahwa variabel disiplin belajar (X1) dan motivasi belajar (X2) secara bersamasama berhubungan terhadap variabel prestasi belajar (Y) sebesar 65,9\%.

\section{SIMPULAN}

Dari hasil penelitian dan pembahasan maka simpulan yaitu terdapat hubungan antara disiplin belajar dengan prestasi belajar PKn siswa kelas III SDN Bandungsari 01. Hal ini di tunjukan pada $\mathrm{t}$ hitung $>\mathrm{t}$ table yaitu 5,478 > 2,086; selain itu terdapat hubungan antara motivasi belajar dengan prestasi belajar PKn siswa kelas III SDN Bandungsari 01. Hal ini di tunjukan pada $\mathrm{t}$ hitung $>\mathrm{t}$ table yaitu 5,293> 2,086; dan juga terdapat hubungan antara disiplin belajar dan motivai belajar dengan prestasi belajar PKn siswa kelas III SDN Bandungsari 01. Hal ini diunjukan berdasarkan berdasarkan uji korelasi product moment besarnya angka koefisien determinasi (R Square) adalah 0,659 atau sama dengn $0,659 \times 100 \%=$ $65,9 \%$, angka tersebut mengandung arti bahwa variabel disiplin belajar (X1) dan motivasi belajar (X2) secara bersamasama berhubungan terhadap variabel prestasi belajar (Y) sebesar $65,9 \%$.

Saran-saran yang dapat diberikan yaitu siswa diharapkan meningkatkan disiplin belajar dan motivasi belajarnya, baik disekolah maupun dirumah.Guru diharapkan memperhatikan dan melatih siswa membiasakan diri dalam disiplin belajar karena disiplin belajar berpengaruh cukup kuat terhadap hasil belajar yang diperoleh siswa.

Selain itu, sekolah juga hendaknya bekerjasama dengan orang tua atau wali murid siswa dalam memberikan bimbingan kepada siswa untuk meningkatkan disiplin belajar dan motivasi belajar siswa sehingga dapat mencapai prestasi yang optimal. 
Jurnal KONTEKSTUAL, Volume 01, No. 1, Agustus 2019, pp. 63-69

\section{REFERENSI}

[1] Rahayu, S.A., 2015, Pendidikan Pancasila dan Kewarganegaraan. PT Bumi Aksara. Jakarta

[2] Daryanto, 2013, Strategi dan Tahapan Mengajar, CV Yrama Widya, Bandung

[3] Djamarah dan Zain. 2010. Strategi Belajar Mengajar. Rineka Cipta. Jakarta

[4] Dimyati dan Mujiono. 2009. Belajar dan Pembelajaran. PT Rineka Cipta. Jakarta

[5] Hamalik, Oemar. 2004. Proses Belajar Mengajar. Bumi Aksara. Jakarta

[6] Ahmadi dan Supriyono. 2004. Psikologi Belajar. Rineka Cipta. Jakarta

[7] Sugiyono. 2015. Metode Penelitian Pendidikan. Penerbit Alfabeta. Bandung.

[8] Arikunto, Suharsini. 2013. Prosedur Penelitian Suatu Pendekatan Praktik. PT Rineka Cipta. Jakarta. 